\title{
Critical Success Factors of Digitalization of Kazakhstan Manufacturing Industry
}

\author{
Saltanat Nurbossynova ${ }^{1}$, Azamat Sautbekov ${ }^{1}$, Baiken Zholdaskhan ${ }^{1}$, Yasser Omar Abdallah ${ }^{2}$, Essam Shehab ${ }^{1}$ \\ ${ }^{1}$ School of Engineering and Digital Sciences, Nazarbayev University, Nur-Sultan, Kazakhstan \\ essam.shehab@nu.edu.kz, https://nu.edu.kz/faculty/essam-shehab \\ ${ }^{2}$ School of Aerospace, Transport \& Manufacturing, Cranfield University, Cranfield, Bedford, UK \\ Yasser.Abdallah@cranfield.ac.uk, https://www.cranfield.ac.uk/
}

\begin{abstract}
The digitalization has become a leading trend for developing a stable economy through industry and firm digital transformation. However, there is no unified recipe for the successful implementation of these technologies. This work aims to define Critical Success Factors of digitalization for the manufacturing industry and compare them with Kazakhstani conditions. The methodology is based on the literature review and survey of stakeholders. This paper presents the concept of critical success factors identification and defines the necessity of further research.
\end{abstract}

Keywords- Critical Success Factors, digitalization, manufacturing

\section{INTRODUCTION}

The amount of digital data is increasing with high speed. According to the United Nations Conference on Trade and Development, in 2017 the Global Internet Protocol (IP) traffic achieved 45,000 GB per second, and it is forecasted to reach double this number by 2022 [1]. Thus, digitalization in recent decades has become an essential part of the stable growth of the economy based on digital industry concepts, including the value chain transformation.

In 2015 the World Economic Forum (WEF) launched a multi-year project related to industries digitalization for achieving a more productive way of work. That research includes monitoring the countries' initiatives in the digitalization of different industries to define what factors are critical for the success of the projects [2]. Also, the WEF project is necessary for assessing the effect of digitalization on industries.

The concept of "Success factors" was developed in the 1960-s by Daniel [3] and explained the necessity of providing company top-management with some critical information that drives towards the success of the businesses. Today, the meaning of Critical Success Factors (CSF) has slightly changed. The CSF concept is used for managerial and strategic decision-making to achieve project missions. The theme of developing an algorithm of defining CSF is a topic for many research works in various fields beginning from social and ending with manufacturing spheres. However, there is no adopted unified definition of CSF and methods of identifying it.

Moreover, companies frequently confuse between CSF and the success criteria that are measurable and achievable in time, criteria of the critical success factor. According to Leidecker and Bruno [3], CSF analysis is essential for developing the strategy of the company. The CSF analysis could be performed on three levels: environment (macro), industry and firm (micro).

In Kazakhstan, the process of digital transformation is developing. However, many projects are pushed by the country government because of socio-economic effects and lack of funding. Several projects could be considered as successful due to project achievements. In the manufacturing industry, the level of digitalization is the lowest compared with other industries. Shaiholla et al. [4] defined that only $3 \%$ of all companies in the manufacturing industry correspond to Industry 4.0 requirements. At the same time, according to the Ministry of Industry and Infrastructure Development, \$17 million would be spent on 14 projects realization until 2022 [5].

Moreover, COVID-19 demonstrates the necessity of the manufacturing industry digitalization. Due to selfisolation and quarantine, the industries that were negatively affected by the disease are services and manufacturing industries, and only companies that were digitally prepared perform well.

The work objective is to review literature for defining Critical Success Factors of the manufacturing industry digitalization, determine stakeholders' expectations and their understanding of digitalization and CSF, compare the list of CSF for Kazakhstan with the ones of other countries.

\section{PROBLEM STATEMENT}

Kazakhstan has a well-established mining industry that could be represented by ERG, Arcelor Mittal, Kazakhmys and Kazatomprom companies that could compete with foreign corporations. Thus, Kazakhstan is known for raw materials export. However, there is no manufacturing company that could compete in other than Kazakhstani markets. The industry digitalization could allow those 
companies to improve their efficiency, productivity and even brand recognition. Therefore, it is necessary to understand which factors might play a crucial role in the industry digitalization process.

\section{LITERATURE REVIEW}

The CSF in a traditional way could be divided into three clusters: factors that are related to the country level (political, economic and social issues), industry level (strengths and weaknesses) and firm-level (main stakeholders) [3].

\section{A. Macro Level Factors}

In this section, the literature review on the Critical Success Factors of digital transformation within the environment of developing countries similar to Kazakhstan in political, economic, social and geographical aspects is presented.

A comprehensive study by Shin [6] analyzing the survey responses of IT specialists and government representatives from 53 developing countries is generally in sync with the later studies upon the CSFs. It also compares the CSFs in developing countries to the ones in developed countries. The study reveals that developing countries must meet several unique requirements apart from addressing the CSFs also common to developed countries. The important CSFs familiar to both developed and developing countries are business processes reengineering and technical \& human resources. Moreover, the unique CSFs to developing countries are external financial support, different organizational culture/values and political stability.

Ziemba et al. by studying the experience of egovernment implementation in Poland identify a positive correlation between the country's socio-economic development, technological \& organizational resources and the adoption of the digital transformation project. They name public well-being, human resources \& mentality, ICT infrastructure, law enforcement level, innovative management and leadership support as some of the main factors that facilitate smooth change [7].

Ijaz et al. exploring the successful case of ERP implementation in one of the major state-owned enterprises (SOE) in Pakistan highlight the importance of setting distinct objectives, clarifying scope, analyzing the culture and the human resources in the first phase. As for the second phase, commitment of top management, careful change management, effective information dissemination, adequate training and sound infrastructure are mentioned as the CSFs. Furthermore, in the last phase, factors like end-user satisfaction, labor productivity, continuous technical support \& maintenance are listed among the important ones [8].

To sum up, leadership commitment, competent change champions, robust technological infrastructure, adequate human resources are regarded as the main factors across all the mentioned countries, plus political stability and delicate handling of the external funding are two unique factors to developing countries, especially with authoritarian regimes

\section{B. Industry Level Factors}

Manufacturing digitalization today is the main topic of academic research and business consultants since it is an inalienable part of the company and industry development.

At the industry level, CSFs are considered as the strategical tool for developing company digitalization strategy. Therefore, it is close to Leidecker and Bruno [3] CSF identification and classification. Vogelsang et al. suggested grouping CSF as organizational, environmental and technological. Organizational factors related to firm level factors. Environmental aspects related to communication of the company with other firms in the value chain and the presence of unified standards of digitalization. Technology level assesses the availability of digital technologies, reliability, completeness and infrastructure readiness [9].

Virmani et al. reviewed the literature and chose 15 critical success factors that were discussed with specialists in this sphere, then for understanding which factors had the highest effect on the industry the survey of 140 firms was provided. The CSFs listed in Virmani et al. work were also connected with strategic management, human resources and technologies, the main difference was in including the market factor - sensitiveness to market changes [10].

In Kazakhstan, the Ministry of Industry and Infrastructure Development (MIID) surveyed 120 companies of the manufacturing industry to define the barriers of digitalization and the factors that could lead to positive changes. According to that survey, $42 \%$ of the respondents suppose that there are no available technologies in Kazakhstan and the imported ones are too expensive. Qualified staff (32\%) and funding (30\%) are almost equally important for many companies since the new technologies adoption, and staff training requires some budget. Therefore, companies try to recruit experienced employees so they would not spend money on training. Thus, companies also highlight the positive effect of governmental financial support. The available ICT infrastructure is the main factor for manufacturers located in rural areas [5].

Overall, the industry level CSFs are focused on the management support and employees' readiness (training, level of acceptance, big data analysis and others), and the availability of technologies. At the same time, governmental support was mentioned in all research works as well as the development of the unified standards of digitalization, laws and regulations.

\section{Firm Level Factors}

A study by Robert Jacobi and Elena Brenner explained in more detail about how large companies can survive the digital transformation [11]. Authors claim that the following three critical dimensions can lead to a 
successful transformation, which are leadership \& vision, culture \& people, and corporate processes \& structure. They mentioned that the ability to convey the idea is one of the primary critical factors of a successful project. Only $17 \%$ of the top executives were able to get financial support for their digital initiatives. Moreover, they suggested the "reverse mentoring" where young professionals help to older employees to adapt quickly for new technical improvements. However, the authors recommended large companies to restrict the overuse of digital transformation. Adapting employees to new tasks can reduce the difference between reduction and hiring.

In the paper of Wolf et al., the impact of the digital transformation on different areas of the company is explained. The authors conclude with three main characterizations for successful companies: a change of mentality in the management, creation of condition for innovation, and knowledge exchange within the company [12].

The survey by Fitzgerald et al. has been done by MIT Sloan management review and Capgemini Consulting. Approximately $30 \%$ of all companies have a lack of funding, limitations of IT system, lack of vision, and weak division of responsibility. Besides, most of the organizations did not have urgency on digital transformation [13].

Table 1 shows the list of Critical Success Factors that were defined in the literature.

TABLE I.

HE LIST OF THE CSF FROM LITERATURE REVIEW

\begin{tabular}{|c|c|c|}
\hline № & Critical Success Factor & References \\
\hline 1 & Management support & $\begin{array}{l}\text { Ziemba et al. (2013), Ijaz et al. } \\
\text { (2013), Vogelsang et al. (2019), } \\
\text { Virmani et al. (2018), Jacobi and } \\
\text { Brenner (2017) }\end{array}$ \\
\hline 2 & $\begin{array}{c}\text { Knowledgeable and } \\
\text { innovative management }\end{array}$ & $\begin{array}{l}\text { Ziemba et al. (2013), Virmani et al. } \\
\text { (2018), Liere-Netheler, Packmohr } \\
\text { and Vogelsang (2018), Wolf et al. } \\
\text { (2018) }\end{array}$ \\
\hline 3 & $\begin{array}{l}\text { Strategic planning and } \\
\text { clear goals }\end{array}$ & $\begin{array}{l}\text { Ijaz et al. (2013), Jacobi and } \\
\text { Brenner (2017) }\end{array}$ \\
\hline 4 & $\begin{array}{l}\text { Competent project } \\
\text { champions }\end{array}$ & Vogelsang et al. (2019) \\
\hline 5 & $\begin{array}{c}\text { Well-thought re- } \\
\text { engineering of business } \\
\text { processes }\end{array}$ & Virmani et al. (2018) \\
\hline 6 & Human resources & $\begin{array}{l}\text { Ziemba et al. (2013), Ijaz et al. } \\
\text { (2013), Shin (2008), Vogelsang et } \\
\text { al. (2019), Virmani et al. (2018), } \\
\text { Jacobi and Brenner (2017), } \\
\text { Balasignham (2016) }\end{array}$ \\
\hline 7 & Employees readiness & $\begin{array}{l}\text { Balasignham (2016), Vogelsang et } \\
\text { al. (2019), Virmani et al. (2018) }\end{array}$ \\
\hline 8 & Culture & $\begin{array}{l}\text { Ziemba et al. (2013), Ijaz et al. } \\
\text { (2013), Shin (2008), Vogelsang et } \\
\text { al. (2019) }\end{array}$ \\
\hline 9 & ICT infrastructure & $\begin{array}{l}\text { Ziemba et al. (2013), Ijaz et al. } \\
\text { (2013), Virmani et al. (2018), } \\
\text { Fitzgerald et al. (2013) }\end{array}$ \\
\hline 10 & $\begin{array}{l}\text { Law/Government } \\
\text { support }\end{array}$ & Ziemba et al. (2013) \\
\hline 11 & Communication & Ijaz et al. (2013), Vogelsang et al. \\
\hline
\end{tabular}

\begin{tabular}{|c|c|l|}
\hline & & $(2019)$ \\
\hline 12 & Technology availability & $\begin{array}{l}\text { Ijaz et al. (2013), Shin (2008), } \\
\text { Vogelsang et al. (2019) }\end{array}$ \\
\hline 13 & Funding & $\begin{array}{l}\text { Shin (2008), Fitzgerald et al. } \\
(2013), \text { Balasignham (2016) }\end{array}$ \\
\hline 14 & Customer needs & $\begin{array}{l}\text { Vogelsang et al. (2019), Virmani et } \\
\text { al. (2018) }\end{array}$ \\
\hline
\end{tabular}

\section{CRITICAL SUCCESS FACTORS DEFINING METHODOLOGY}

The critical success factors analysis methodology is based on defining the list of factors through a literature review (Table 1). Some more specific factors were added to this list using PEST and SWOT analyses, stakeholders expectations and needs were translated in the form of critical success factors. Also, factors from the survey of the MIID about the readiness of the industry to digitalization were implemented in the list.

A four-level scale was used for defining the most valuable factors that could positively affect the digitalization process: high, medium, low and no influence. The four-level scale allows to specify responses. For assessment, the following questionnaire was provided to respondents.

TABLE II. THE INFLUENCE LEVEL OF CSFS QUESTIONNAIRE

\begin{tabular}{|c|c|c|c|c|c|}
\hline \multirow[t]{2}{*}{ Cluster } & \multirow[t]{2}{*}{ Critical Success Factor } & \multicolumn{4}{|c|}{$\begin{array}{l}\text { Level of } \\
\text { influence }\end{array}$} \\
\hline & & $\mathbf{H}$ & $\mathbf{M}$ & $\mathbf{L}$ & $\mathbf{0}$ \\
\hline \multirow{12}{*}{ Organizational } & Management support & & & & \\
\hline & $\begin{array}{c}\text { Knowledgeable and innovative } \\
\text { management }\end{array}$ & & & & \\
\hline & Strategic planning & & & & \\
\hline & Clear goals & & & & \\
\hline & $\begin{array}{c}\text { Well-thought algorithm of } \\
\text { business processes re- } \\
\text { engineering }\end{array}$ & & & & \\
\hline & The competence of the team & & & & \\
\hline & The composition of the team & & & & \\
\hline & Experienced workers & & & & \\
\hline & Training & & & & \\
\hline & Culture & & & & \\
\hline & $\begin{array}{c}\text { Communication within the } \\
\text { organization }\end{array}$ & & & & \\
\hline & Funding & & & & \\
\hline \multirow[t]{7}{*}{ Environmental } & Government support & & & & \\
\hline & Government financial support & & & & \\
\hline & Unified standards and rules & & & & \\
\hline & $\begin{array}{c}\text { Communication between } \\
\text { organizations/ effective } \\
\text { collaborations }\end{array}$ & & & & \\
\hline & Supply chain management & & & & \\
\hline & Customer needs & & & & \\
\hline & Transparency in operations & & & & \\
\hline \multirow[t]{3}{*}{ Technology } & ICT infrastructure & & & & \\
\hline & Technology availability & & & & \\
\hline & Technology reliability & & & & \\
\hline
\end{tabular}

It was planned to interview several stakeholders that were defined in the stakeholder analysis, however, due to quarantine, only a few of them were surveyed: the representatives of the MIID (2 persons) and representatives of four manufacturing companies. 


\section{CRITICAL SUCCESS FACTORS OF DigITALIZATION IN KAZAKHSTANI MANUFACTURING INDUSTRY}

This section of the work consists of four parts: PEST analysis, SWOT, stakeholders' expectations, and the effect of each factor according to interviews with some stakeholders. First, PEST analysis considers high level (environmental) factors related to political and economic aspects of digitalization in Kazakhstan. The analysis of manufacturing industry strengths and weaknesses demonstrates the readiness of the industry to implement digitalization fully. This analysis was completed with stakeholder expectations and needed further analysis. The work provides a list of factors that are critical for digital transformation in the Kazakhstani manufacturing industry.

\section{A. PEST and SWOT analysis}

The template is designed so that author affiliations are not repeated each time for multiple authors of the same affiliation. Please keep your affiliations as succinct as possible (for example, do not differentiate among departments of the same organization). The main strengths and weaknesses of the manufacturing industry have been identified based on the PEST analysis and the survey results provided by the MIID.

Political factors. The government is serving as a driving force of the digital transformation in Kazakhstan. It developed a national program named "Digital Kazakhstan" at the end of 2017 with concrete objectives and roadmap to achieve the goal of rising from the 52nd to the 25th position in the world digitalization ranking [14]. The government also showed a severe attitude by allocating a substantial sum of more than 700 million USD [15]. It also developed the Strategic Plan 2025, specifying seven systemic reforms and policies to be implemented, one of which is technological modernization and digitalization [16]. Along with that the MIID together the World Bank specialists began the development of "National Investment Strategy" and assigned National Company "Kazakh Invest" to attract and coordinate the distribution of foreign investments into Industry 4.0 projects [17].

In addition to that, the government concluded strategic Production-sharing agreements (PSAs) with significant oil \& gas companies like Tengizchevroil, NCOC and KPO to secure their projects from adjustments made to national regulations and ensure substantial foreign direct investment (FDI) into the extractive industry. The latest confirmation of the success of this policy came in the form of a $\$ 50$ billion investment in the Kashagan project alone, which made it the most expensive energy project on Earth [18].

Economic factors. The country belongs to the uppermiddle-income economy with positive annual GDP growth. However, the national economy is highly dependent on oil \& gas and mining products, and the fall of oil prices in the world has reduced the profits obtained from oil export. Furthermore, the instability of national currency and its devaluation do not help the situation at all. This instability will adversely affect the prices of imported technology and equipment since most of them are not locally manufactured.

The state's role in the national economy is abnormally large. State-owned enterprises (SOEs) account for about $2 / 3$ of all assets, and virtually all concentrated in three national holdings like Samruk-Kazyna, Baiterek and KazAgro. This role causes problems such as economic inefficiency, decisions taken for political reasons rather than based on market trends. Furthermore, it also results in the underdeveloped private sector; the small and medium enterprises (SMEs) produce goods, works and services amounting to less than $20 \%$ of national GDP, which is a low indicator for an upper-middle-income economy [18]. Plus, the management of some legacy large manufacturing companies have become so addicted to state subsidies and direct state or quasi-state orders that they do not feel the necessity to modernize and attract investments in technology [19].

Social factors. According to the world prosperity index, Kazakhstan ranks 68th overall, it enjoys a relatively high rank of being 34th in education and has steadily risen by 50 positions to rank $72 \mathrm{nd}$ in the Social Capital aspect in the last decade [20]. Besides, there is an upward trend in the labor force, makes $67 \%$ of the population, due to rapid population growth [21]. This trend gives an optimistic view of the future.

However, according to Kazakhstan Institute for Strategic Studies chief researcher Karatayeva (n.d) [22], there is an acute lack of ICT and cybersecurity specialists, and according to Fraunhofer Institute of Applied Research $20 \%$ of technology, organizational and personnel base is ready for 4.0. The labor productivity is very low compared to developed countries, for example, in agriculture, the degree of this lag reaches 12-15 times, in the mining industry - 5-10 times, in the manufacturing industry - 2-4 times as low [16].

Furthermore, despite the growing complexity and knowledge-intensiveness of the manufacturing industry, Kazakhstan contributes only $0.15 \%$ of GDP to R\&D compared to $1.2 \%$ of GDP in Russia and Brazil, $2.2 \%$ in Australia.

Another factor to be considered is the spread of COVID-19 pandemic, and the issues caused by lockdown could set back economic growth. The World Bank forecasts up to a $3 \%$ GDP reduction in 2020; this would significantly raise the poverty rate in the country. On the other hand, it may spur the development of e-commerce and turn the entrepreneurs' attention towards digital solutions. Distance working may become a significant trend, and result in the reduction of office renting expenditures [23].

The country is still lagging in terms of corruption rate ranking 113th out of 180 countries on the list of Transparency International despite steadily improving from 2015 [24]. Moreover, corruption can nullify or at 
least hinder all the efforts and plans declared by the government.

Technological factors. Shaiholla et al. claim that around $80 \%$ of manufacturing companies in Kazakhstan are at Industry 2.0 level, $17 \%$ of the firms are in mid Industry 2.0-3.0 stage and staggering 3\% of manufacturing enterprises can boast being at Industry 3.0 level [4]. The E-intensity ranking provided by BCG suggests that Kazakhstan is at a starter level being 51st out of analyzed 73 countries due to current level of technology and automation, lack of entrepreneurial initiative $\&$ infrastructure to support start-ups, limited development of electronic commerce and still a significant proportion of paper workflow [14].

Nevertheless, according to the same source, Kazakhstan is ahead of BRIC countries in internet infrastructure, which serves as a solid background for the development of other digitalization components. Thanks to the launching of the KazSat space system satellites, services are rendered to several telecom operators, broadband Internet access and data transmission are delivered throughout Kazakhstan at a lower price [25].

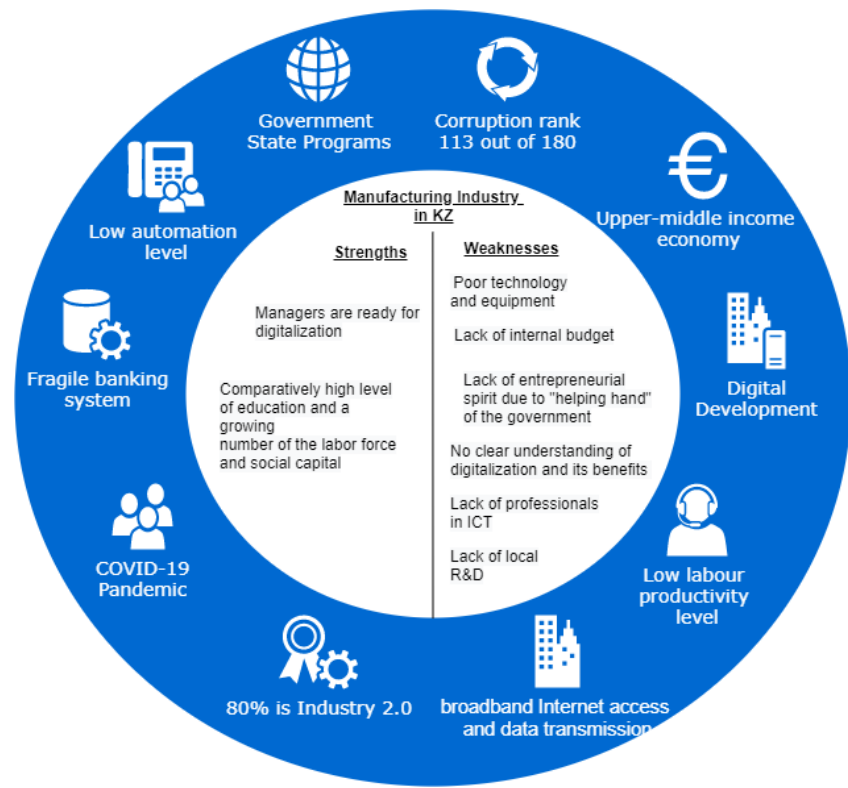

Figure 1. Manufacturing industry strengths, weaknesses and country level factors

\section{B. Interview Results}

The numbers are given in Table 4 shows how many people scaled the influence of the factors, where:

$\mathrm{H}$ - high influence level.

M - medium influence level,

$\mathrm{L}$ - low influence level,

$0-$ no influence.

The interview results demonstrate that the highest scores were given to factors related to technology, human resources and governmental support. During the interviews, it was highlighted that people do not fully comprehend the meaning of "Knowledgeable and innovative management", it is necessary to explain what aspects are included in this term.

TABLE III. THE INFLUENCE LEVEL OF CSFS

\begin{tabular}{|c|c|c|c|c|c|}
\hline \multirow[t]{2}{*}{ Cluster } & \multirow[t]{2}{*}{ Critical Success Factor } & \multicolumn{4}{|c|}{$\begin{array}{l}\text { Level of } \\
\text { influence }\end{array}$} \\
\hline & & $\mathbf{H}$ & $\mathbf{M}$ & $\mathbf{L}$ & $\mathbf{0}$ \\
\hline \multirow{12}{*}{ Organizational } & Management support & 4 & & 2 & \\
\hline & $\begin{array}{l}\text { Knowledgeable and innovative } \\
\text { management }\end{array}$ & & 3 & 1 & \\
\hline & Strategic planning & & 3 & 2 & \\
\hline & Clear goals & & 3 & 3 & \\
\hline & $\begin{array}{c}\text { Well-thought algorithm of } \\
\text { business processes re- } \\
\text { engineering }\end{array}$ & & & 1 & \\
\hline & The competence of the team & & 3 & 3 & \\
\hline & The composition of the team & & 2 & 4 & \\
\hline & Experienced workers & 4 & 2 & & \\
\hline & Training & 4 & 2 & & \\
\hline & Culture & & & 4 & 2 \\
\hline & $\begin{array}{c}\text { Communication within the } \\
\text { organization }\end{array}$ & & 3 & 3 & \\
\hline & Funding & & 3 & 3 & \\
\hline \multirow[t]{7}{*}{ Environmental } & Government support & 4 & 2 & & \\
\hline & Government financial support & 4 & 2 & & \\
\hline & Unified standards and rules & 3 & 1 & 1 & \\
\hline & $\begin{array}{c}\text { Communication between } \\
\text { organizations/ effective } \\
\text { collaborations }\end{array}$ & & & 1 & 1 \\
\hline & Supply chain management & 1 & 2 & 1 & 1 \\
\hline & Customer needs & & 1 & 2 & \\
\hline & Transparency in operations & & & 1 & \\
\hline \multirow[t]{3}{*}{ Technology } & ICT infrastructure & 4 & & & \\
\hline & Technology availability & 4 & & & \\
\hline & Technology reliability & 4 & & & \\
\hline
\end{tabular}

Considering the results of conducted analyses of the local situation at country, industry and company levels through PEST, SWOT, Stakeholders analysis and the interviews it could be concluded that most of the critical success factors are relevant to those extracted from the literature review.

There is a strong presence of state-owned enterprises among the leading manufacturing companies in Kazakhstan. This cardinally affects the whole landscape of the industry, especially the decision-making processes, which in turn define the flow of the transformation. The heavy reliance of the manufacturing firms on the government support \& direction, the atrophied entrepreneurial spirit together with the top-down approach from the government negatively impact the digitalization process. On the other hand, the interviewees indicate the high importance of government support in terms of securing the legal base and financial aid.

The overall answers show that the managers do not understand the impact of culture, training and expectations of employees from digitalization, organizational factors are put on the second or even third phase of the transformation. Firstly, managers purchase technologies and find people who could work with those technologies, 
and only after that, they train employees without understanding their needs.

The work has limitations due to quarantine conditions, which leads to minimal sample size analysis, and it is necessary to continue further research work.

\section{CONCLUSION}

Digitalization is an increasing trend in the world that leads to efficiency enhancement, productivity growth in industries and - as a result — to a stable economy. Thus, any country and industry must stay in this trend. This work aimed to observe existing research studies of the Critical Success Factors and define a list of them appropriate for the Kazakhstani manufacturing industry.

The literature review demonstrates that the CSF is a trending topic for business consultants and academics. In sum, all factors could be divided into three clusters related to external factors, organizational factors and technologies.

In Kazakhstan, according to the MIID survey, governmental financial support plays the main role in companies digitalization due to lack of funding and lack of local Kazakhstani technologies. Moreover, the government is the main initiator and motivator of digitalization. The aim of the existing "Digital Kazakhstan" state program is to improve ICT infrastructure and make it available for both rural and urban areas, and to create a digital nation

\section{ACKNOWLEDGMENT}

The authors would like to thank Nazarbayev University for funding this article under the Faculty Development Competitive Research Grant Program (FCDRGP) Grant No. 110119FD4524. .

\section{REFERENCES}

[1] "Digital Economy Report 2019 (Overview) - UNCTAD." [Online]. Available:

https://unctad.org/en/PublicationsLibrary/der2019_overview_en.p df. [Accessed: 13-Apr-2020];

[2] "Digital Transformation Initiative." [Online]. Available: https://reports.weforum.org/digital-transformation/. [Accessed: 13-Apr-2020];

[3] J. K. Leidecker and A. V. Bruno, "Identifying and using critical success factors," Long Range Planning, vol. 17, no. 1, pp. 23-32, 1984 ;

[4] S. Shaiholla, A. Bekov, and I. A. Ukaegbu, "Industry 4.0: Redefining Manufacturing in Kazakhstan," 2019 21st International Conference on Advanced Communication Technology (ICACT), 2019;

[5] Digital manufacturing industry report, Nur-Sultan: The Ministry of Industry and Infrastructure Development , 2019, pp. 30-32;

[6] S. Shin, "Implementing e-government in developing countries: Its unique and common success factors", American Political Science Association, 2008;

[7] E. Ziemba, T. Papaj, and R. Zelazny, "A model of success factors for e-government adoption - the case of Poland", Issues in Information Systems, vol. 14, no. 2, 2013;

[8] A. Ijaz, R. K. Malik, R. N. Lodhi, U. Habiba and S. M. Irfan, “A qualitative study of the critical success factors of ERP system-A case study approach", In Proceedings of the 2014 International
Conference on Industrial Engineering and Operations Management, pp. 2556-2566, 2014;

[9] K. Vogelsang, K. Liere-Netheler, S. Packmohr, and U. Hoppe, "Success factors for fostering a digital transformation in manufacturing companies," Journal of Enterprise Transformation, pp. 1-22, 2019;

[10] N. Virmani, R. Saha, and R. Sahai, "Empirical assessment of critical success factors of leagile manufacturing using fuzzy DEMATEL approach," International Journal of Agile Systems and Management, vol. 11, no. 4, p. 293, 2018;

[11] R. Jacobi and E. Brenner, "How Large Corporations Survive Digitalization," Digital Marketplaces Unleashed, pp. 83-97, 2017 ;

[12] M. Wolf, A. Semm, and C. Erfurth, "Digital Transformation in Companies - Challenges and Success Factors," Innovations for Community Services Communications in Computer and Information Science, pp. 178-193, 2018;

[13] M. Fitzgerald, N. Kruschwitz, D. Bonnet and M. Welch, "Embracing digital technology - a new strategic imperative", MIT Sloan Management Review Research Report, 2013. Available via Capgemini Consulting;

[14] "Special issue: Kazakhstan. BCG Review." [Online]. Available: https://image-

src.bcg.com/Images/BCG_Review_KZ_May_tcm27-193677.pdf. [Accessed: 13-Apr-2020];

[15] A. Muminov, "Chto zhdet "Tsifrovoy Kazakhstan"?" [What awaits Digital Kazakhstan?]. [Online]. Available: https://kapital.kz/tehnology/77003/chto-zhdet-tsifrovoykazakhstan.html, 2019;

[16] National Program (n.d.). "Strategicheskiy Plan 2025". [Strategic Plan 2025]. [Online]. Available: https://primeminister.kz/ru/documents/gosprograms/stratplan2025 ;

[17] K. Zhandybayev, "Industry 4.0: how the fourth industrial revolution works”. [Online]. Available: https://strategy2050.kz/en/news/48918/, 2017

[18] B. Bohr, B. Brauer, N. Gould-Davies, N. Kassenova, J. Lillis, K Mallinson, J. Nixey and D. Satpayev, "Kazakhstan: Tested by Transition". (Chatham House Report). [Online]. Available: https://www.chathamhouse.org/sites/default/files/2019-11-27Kazakhstan-Tested-By-Transition.pdf

[19] "Lejachiy kamen: v chem problema razvitiya kazahstanskogo neftegazovogo mashinostroeniya" [Lying stone: what is the problem of the development of Kazakhstan's oil and gas engineering]. Forbes. [Online]. Available: https://forbes.kz//process/economy/lejachiy_kamen_v_chem_prob lema_razvitiya_kazahstanskogo_neftegazovoe_mashinostroeniya/

[20] Prosperity. (2019). [Online]. Available: https://prosperitysite.s3accelerate.amazonaws.com/9815/7408/0986/Kazakhstan_2019_PI countryprofile.pdf

[21] Coface. (2020). [Online]. Available: https://www.coface.com/Economic-Studies-and-CountryRisks/Kazakhstan

[22] L. Karatayeva (n.d.). "The Development of Human Capital Within the Transition of Kazakhstan to Industry 4.0: Directions, Achievements and Risks", Kazakhstan Institute for Strategic Studies, 2020. $\quad$ [Online]. Available: http://www.kisi.kz/index.php/en/publications/58-karataeva-lesyarollanovna/2401-the-development-of-human-capital-within-thetransition-of-kazakhstan-to-industry-4-0-directions-achievementsand-risks

[23] "Kazakhstan overview", World Bank, 2020. [Online]. Available: https://www.worldbank.org/en/country/kazakhstan/overview\#3

[24] "Kazakhstan. Transparency International. (2019)." [Online]. Available: https://www.transparency.org/country/KAZ

[25] "Kazakhstan nameren predostavlyat uslugi sputnikovoy svyazi v Tsentralnoy Azii". [Kazakhstan intends to provide satellite communications services in Central Asia]. Kursiv, 2019. [Online]. Available: https://kursiv.kz/news/kompanii-i-rynki/201902/kazakhstan-nameren-predostavlyat-uslugi-sputnikovoy-svyazi 
2021-06-29

\section{Critical success factors of digitalization of Kazakhstan manufacturing industry}

Nurbossynova, Saltanat

IEEE

Nurbossynova S, Sautbekov A, Zholdaskhan B, et al., (2021) Critical success factors of digitalization of Kazakhstan manufacturing industry. In: 2021 IEEE International Conference on Smart Information Systems and Technologies (SIST), 28-29 April 2021, Nur-Sultan https://doi.org/10.1109/SIST50301.2021.9465926

Downloaded from Cranfield Library Services E-Repository 